\title{
Yield and Nutrient Losses Due to Weeds in Prominent Cropping Sequences under Mid Hills of Himachal Pradesh, India
}

\author{
Gurpreet Singh*, Pawan Pathania, S.C. Negi and S.S. Rana
}

Department of Agronomy, Forages and Grassland Management, COA, CSK Himachal Pradesh Himachal Pradesh Agricultural University, Palampur-176 062, India

*Corresponding author

\section{A B S T R A C T}

\section{Keywords}

Cropping systems,

Weed diversity,

Nutrient losses,

Yield losses

\section{Article Info}

Accepted:

04 October 2018

Available Online:

10 November 2018
The present study was carried out in a continuing experiment at the Bhadiarkhar farm of the CSK HPKV. Eight cropping sequences $\left[\mathrm{C}_{1^{-}}\right.$'rice - wheat', $\mathrm{C}_{2^{-}}$'rice - pea - summer squash', $\mathrm{C}_{3^{-}}$'okra - radish - onion', $\mathrm{C}_{4^{-}}$'turmeric - pea - summer squash', $\mathrm{C}_{5^{-}}$'rice lettuce - potato', $\mathrm{C}_{6^{-}}$'rice - palak - cucumber', $\mathrm{C}_{7^{-}}$'rice - broccoli - radish', $\mathrm{C}_{8^{-}}$ 'colocasia - pea + coriander'] were evaluated during 2016-17. There were 24 weed species which invaded different cropping systems. During kharif, Ageratum sp. (28\%), Cynodon dactylon (20\%) and Commelina benghalensis (19\%) were the predominant weeds. In rabi, Phalarisminor (63\%) was the most dominating weed followed by Coronopus didymus $(10 \%)$ and Spergulla arvensis $(6 \%)$. In kharif, weed flora was more diverse in $\mathrm{C}_{3}, \mathrm{C}_{4}$ and $\mathrm{C}_{8}$ i.e. okra, turmeric and colocasia based sequences, respectively and weed diversity was lower in rice-based sequences. In rabi, highest diversity of weed species was in rice-wheat sequence. $\mathrm{C}_{8}$ had highest RGEY among all the crop sequences. Weeds inflicted huge yield losses ranging from 30.6 in $\mathrm{C}_{1}$ to $59.2 \%$ in $\mathrm{C}_{6}$. $\mathrm{N}$ depletion by weeds ranged from 16.2 in $\mathrm{C}_{6}$ to $48.5 \mathrm{~kg} / \mathrm{ha} /$ annum in $\mathrm{C}_{3}, \mathrm{P}$ from 3.1 in $\mathrm{C}_{5}$ to $8.1 \mathrm{~kg} / \mathrm{ha} /$ annum in $\mathrm{C}_{3}$ and $\mathrm{K}$ from 4.8 in $\mathrm{C}_{6}$ to $13.2 \mathrm{~kg} / \mathrm{ha} /$ annum in $\mathrm{C}_{3}$.

\section{Introduction}

Rice- wheat is the prominent cropping sequence of mid hills of Himachal Pradesh. Despite enormous growth of rice-wheat system, reports of stagnation in the productivity, with possible decline in production in future, have raised doubts on its sustainability (Ramanjaneyulu et al., 2006). Weed infestation is a major obstacle in productivity enhancement in mid hills of Himachal Pradesh. Weeds can reduce the production of rice by $10-100 \%$ and wheat by
10-60\% (Rao et al., 2014; Yaduraju et al., 2015). Farmers in the region cannot make the best use of fertile land, plentiful water supplies and abundant plant genetic resources, despite climatic conditions that favour cultivation of several crops such as rice, wheat, maize, potato and other vegetables like okra, radish and colocasia.

Controlling weeds satisfactorily increases the cost of cultivation of the crop as well as deplete resource base (Buriro et al., 2003). Most of farmers of Himachal Pradesh are 
small, marginal and are unable to bear the heavy costs associated in carrying out weed management operations. Chemical weed control creates many problems such as development of herbicide resistant weeds, shifting weed flora and environmental pollution. Different planting and harvest dates among crops can prevent or reduce weed establishment or seed production. Furthermore, crop diversity can improve crop growth (Kirkegaard and Hunt, 2010), thereby increasing crop competitiveness and tolerance to weeds (Anderson, 2011). Rotations composed of a diversity of crops with different life cycles are a sound option to manage weeds and critical component of integrated weed management (Colbach et al., 2014). To ensure safe guard against environmental pollution and to reduce chances of shifting of weed flora and development of herbicide resistant weeds, crop rotations which allow minimum weed infestation and yield losses, appear to have great importance. Therefore, studying weed diversity in diversified cropping system and associated yield and nutrient losses have immense significance.

\section{Materials and Methods}

The present study was carried out in a continuing experiment at the Bhadiarkhar farm of the university. The experiment was started in kharif 2014. Eight cropping sequences $\left[\mathrm{C}_{1^{-}}\right.$'rice - wheat', $\mathrm{C}_{2^{-}}$'rice - pea - summer squash', $\mathrm{C}_{3^{-}}$'okra - radish - onion', $\mathrm{C}_{4^{-}}$'turmeric - pea - summer squash', $\mathrm{C}_{5^{-}}$ 'rice - lettuce - potato', $\mathrm{C}_{6^{-}}$'rice - palak cucumber', $\mathrm{C}_{7^{-}}$'rice - broccoli - radish', $\mathrm{C}_{8^{-}}$ 'colocasia - pea + coriander'] were evaluated during 2016-17 in RBD with four replications. The crops were raised in accordance with the recommended package of practices for the region. Gross plot size was $26.4 \mathrm{~m}^{2}$ and a part of plot $(2 \mathrm{~m} \times 2 \mathrm{~m})$ was left weedy (without herbicide spray or hand weeding). The economical yield of crops was taken from net plot and was converted into t/ha. The yield from weedy plot $(2 \mathrm{~m} \times 2 \mathrm{~m})$ was recorded separately and also converted to t/ha. Yield losses were computed by comparing per hectare yield of the main and weedy plot.

In order to draw a valid conclusion the yield of individual crop was converted to RGEY (rice grain equivalent yield) using formula:

RGEY $(\mathrm{t} / \mathrm{ha})=$ Economical yield of a crop e.g. wheat (t/ha) X [Price ( $\square / \mathrm{kg}$ ) of same crop e.g. wheat / Price ( $\square / \mathrm{kg}$ ) of rice]

The RGEY of component crops in each system were added to get the total RGEY of the cropping systems.

Species-wise weed count and samples for weed dry weight were taken at monthly interval from $25 \mathrm{~cm} \times 25 \mathrm{~cm}$ quadrate/area at two sites in each main plot. The weed count so obtained was converted into No./square metre by multiplying the mean count of the weed with factor 16. These samples for dry weight were oven dried at a temperature of $70^{\circ} \mathrm{C}$ till constant weight. The dry matter thus recorded was also multiplied by the factor 16 to obtain weed dry weight/square metre. Weed samples collected at termination of both seasons were ovendried, ground and analysed for nitrogen (Jackson, 1973), phosphorus (Jackson, 1973) and potassium (Black, 1965). The uptake of N, $\mathrm{P}$ and $\mathrm{K}$ was calculated by multiplying nutrient content with corresponding dry weight and expressed in $\mathrm{kg} / \mathrm{ha}$.

The data on weed dry weight and crop yield were subjected to statistical analysis using the techniques of analysis of variance as described by Gomez and Gomez (1984) and compared at 5 percent level of significance. Weed dry weight data showed variation, therefore, were analyzed after subjecting the original data to square root transformation $(\sqrt{x+0.5})$. 


\section{Results and Discussion}

\section{Surveillance and distribution of weed species}

Total of 24 weed species were found associated in different cropping sequences. The weed flora in rabi was more diverse than in kharif (Fig. 1). In rabi, Phalaris minor was the most dominating weed contributing 63\% to total weed flora followed by Coronopus didymus (10\%), Spergulla arvensis (6\%), Ageratum sp. (4\%), Trifolium repens (3\%), Cynodon dactylon (3\%) and Polygonum sp. $(4 \%)$. Other weeds as a whole made up $7 \%$.

Ageratum was the most dominant weed in kharif. It contributed about $28 \%$ of total weed flora. Cynodon dactylon and Commelina benghalensis were next in dominance constituting $20 \%$ and $19 \%$ of total weed flora, respectively. Brassica sp. and Monochoria vaginalis were other important weeds contributing 11 and $10 \%$, respectively to total weed flora. Cyprus sp. and other weeds each constituted $6 \%$ to total kharif weed flora.

\section{Weed dry weight}

The dry matter accumulation during kharif increased with time (Table 1). Maximum dry weight under the cropping systems was at end of season i.e. during October. There were contrasting differences among the cropping systems in influencing dry weight accumulation during kharif.

Differences in dry weight accumulation among the cropping systems were very much clear in rabi. The dry matter accumulation during rabi decreased with time due to imposition of treatment but, after March dry weight increased many folds. The maximum dry matter accumulation was recorded at the termination of season during April and May. Significantly higher dry weight was recorded in 'rice-wheat', 'rice-pea-summer squash' and 'colocasia-pea + coriander'. In kharif dry weed weight during July and October significantly varied under the cropping systems. Similarly cropping system brought significant variation in the dry weight of rabi weeds during March and April.

Average dry weight of kharif and rabi weeds significantly varied among different cropping systems (Table 1). In kharif highest average dry weight was in 'okra-radish-onion' being at par with 'turmeric-pea-summer squash' and 'colocasia-pea + coriander'. Lowest dry weight was recorded in 'rice-pea-summer squash' being at par with 'rice-lettuce-potato', 'rice-broccoli-radish', 'rice-wheat' and 'ricepalak-cucumber'. This concludes that ricebased cropping systems had lower weed dry weight might be due to continuous submergence and were statistically at par with each other. The other upland cropping systems had higher weed dry weight being statistically at par with each other.

In rabi, average dry weight was highest in 'colocasia-pea + coriander' being at par with 'rice-wheat', 'rice-pea-summer squash' and 'okra-radish-onion'. Minimum dry weight was in 'rice-palak-cucumber' being at par with 'turmeric-pea-summer squash', 'rice-lettucepotato' and 'rice-broccoli-radish'.

\section{Rice grain equivalent yield}

The data on yield of the main product of individual crop and RGEY have been summarized in Table 2. 'Colocasia - pea + coriander' resulted in significantly higher RGEY compared to other cropping systems due to higher tonnage of colocasia. This system was followed by 'rice - lettuce potato' and 'okra - radish - onion'. The higher yield in these systems was owed to higher tonnage of lettuce and potato and radish and onion, respectively. 
Table.1 Dry weight $\left(\mathrm{g} / \mathrm{m}^{2}\right)$ of weeds in different cropping systems

\begin{tabular}{|c|c|c|c|c|c|c|c|c|c|c|c|c|}
\hline \multirow{2}{*}{$\begin{array}{l}\text { Cropping } \\
\text { system }\end{array}$} & \multicolumn{7}{|c|}{$r a b i$} & \multicolumn{5}{|c|}{ kharif } \\
\hline & DEC & JAN & FEB & MARCH & APRIL & MAY & Mean & JULY & AUG & SEP & OCT & Mean \\
\hline \multirow[t]{2}{*}{$\mathrm{C}_{1}$} & 7.4 & 5.8 & 5.8 & 5.6 & 12.9 & 7.7 & 8.1 & 4.7 & 8.6 & 7.0 & 6.2 & 6.9 \\
\hline & (62) & (34) & (33) & (32) & (167) & (65) & (66) & (22) & $(75)$ & (49) & (41) & (47) \\
\hline \multirow[t]{2}{*}{$\mathrm{C}_{2}$} & 8.2 & 6.1 & 6.0 & 6.2 & 9.8 & 10.1 & 8.0 & 5.5 & 7.8 & 5.1 & 5.4 & 6.1 \\
\hline & (72) & (37) & (36) & (39) & (98) & (105) & (65) & (31) & (62) & (27) & (29) & (37) \\
\hline \multirow[t]{2}{*}{$\mathrm{C}_{3}$} & 7.8 & 5.7 & 5.0 & 5.7 & 6.8 & 11.4 & 7.7 & 8.1 & 8.2 & 9.4 & 12.6 & 9.8 \\
\hline & (61) & (32) & (25) & (33) & (52) & (174) & (63) & (66) & (72) & (89) & (162) & (97) \\
\hline \multirow[t]{2}{*}{$\mathrm{C}_{4}$} & 6.2 & 5.9 & 5.8 & 5.7 & 6.1 & 8.1 & 6.5 & 7.3 & 7.7 & 7.9 & 10.2 & 8.4 \\
\hline & (40) & (34) & (36) & (33) & (38) & (69) & (42) & (54) & (62) & (63) & (106) & (71) \\
\hline \multirow[t]{2}{*}{$\mathrm{C}_{5}$} & 7.0 & 6.5 & 4.6 & 3.7 & 8.4 & 8.6 & 6.9 & 5.3 & 7.2 & 6.1 & 5.6 & 6.2 \\
\hline & (52) & (43) & (21) & (13) & (77) & (78) & (47) & (29) & (53) & (39) & (33) & (39) \\
\hline \multirow[t]{2}{*}{$\mathrm{C}_{6}$} & 6.7 & 5.9 & 4.6 & 5.1 & 6.6 & 7.3 & 6.2 & 5.8 & 8.2 & 8.1 & 4.8 & 7.2 \\
\hline & (45) & (35) & (21) & (26) & (45) & (53) & (38) & (34) & (69) & (82) & (26) & (53) \\
\hline \multirow[t]{2}{*}{$\mathrm{C}_{7}$} & 8.1 & 6.8 & 6.6 & 0.7 & 5.3 & 9.6 & 6.9 & 6.7 & 7.0 & 5.8 & 5.2 & 6.3 \\
\hline & (70) & (46) & (43) & (0) & (29) & (94) & (47) & (45) & (49) & (34) & (27) & (39) \\
\hline \multirow[t]{2}{*}{$\mathrm{C}_{8}$} & 9.5 & 6.7 & 6.6 & 6.1 & 13.0 & 10.1 & 9.1 & 7.1 & 7.2 & 8.0 & 11.0 & 8.6 \\
\hline & (92) & (45) & (45) & (37) & (178) & (102) & (83) & (51) & (51) & (64) & (134) & (75) \\
\hline SEm \pm & 0.80 & 0.34 & 0.51 & 0.43 & 1.19 & 1.50 & 0.59 & 0.55 & 0.70 & 1.00 & 1.09 & 0.50 \\
\hline $\begin{array}{l}\text { LSD } \\
(P=0.05)\end{array}$ & NS & NS & NS & 1.3 & 3.5 & NS & 1.7 & 1.6 & NS & NS & 3.2 & 1.5 \\
\hline
\end{tabular}

* Figures in the parentheses are the means of original values. Data transformed to square root transformation $(\sqrt{x+0.5})$

$\mathrm{C}_{1^{-}}$'rice - wheat', $\mathrm{C}_{2^{-}}$'rice - pea - summer squash', $\mathrm{C}_{3^{-}}$'okra - radish - onion', $\mathrm{C}_{4^{-}}$'turmeric - pea - summer squash', $\mathrm{C}_{5^{-}}$'rice - lettuce - potato'., $\mathrm{C}_{6^{-}}$'rice - Palak - cucumber', $\mathrm{C}_{7^{-}}$'rice - broccoli - radish', $\mathrm{C}_{8^{-}}$'colocasia pea + coriander'

Table.2 Effect of crop sequences on Rice Grain Equivalent Yield (RGEY)

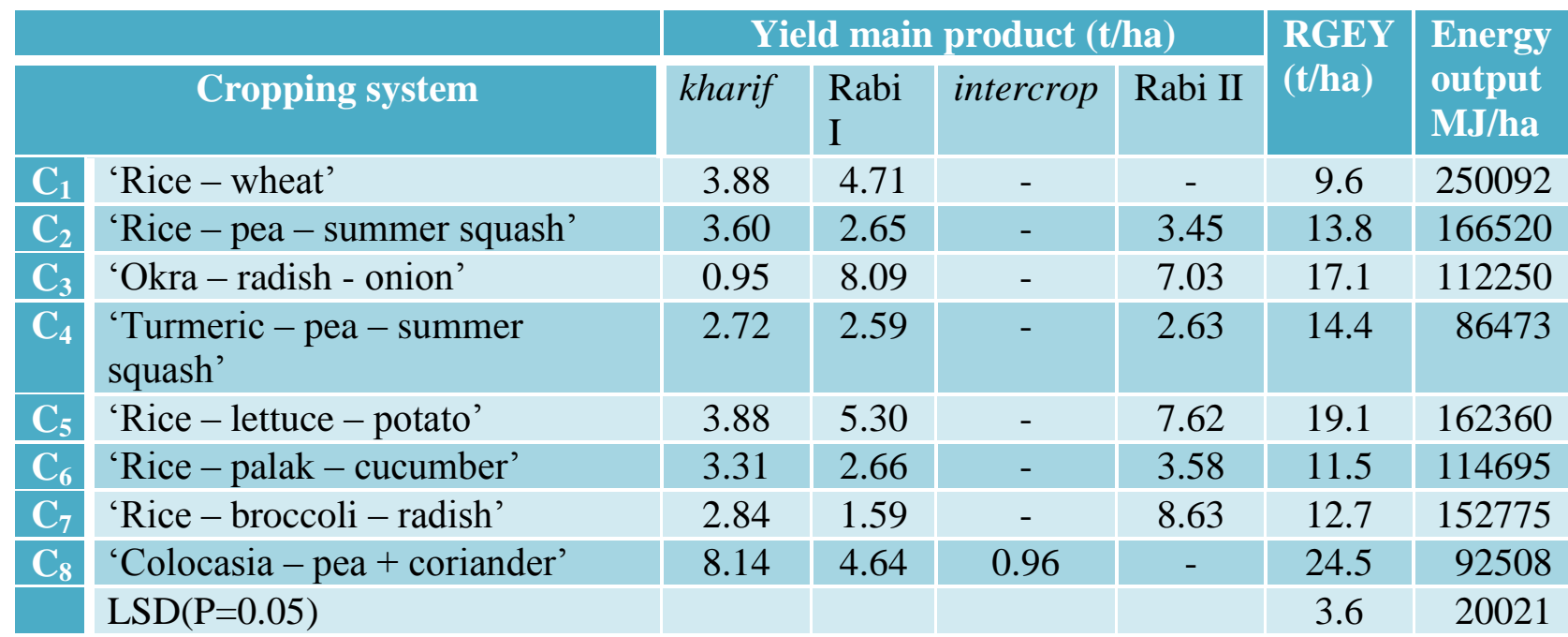


Table.3 Cropping systems influence on NPK depletion ( $\mathrm{kg} / \mathrm{ha}$ ) by weeds during rabi and kharif

\begin{tabular}{|l|l|c|c|c|c|c|c|c|c|c|c|}
\hline \multicolumn{1}{|c|}{ Cropping system } & \multicolumn{3}{|c|}{ Rabi } & \multicolumn{3}{|c|}{ Kharif } & \multicolumn{2}{|c|}{ Total Rabi + Kharif } \\
\hline $\mathrm{C}_{1}$ & 'Rice - wheat' & $\mathrm{N}$ & $\mathrm{P}$ & $\mathrm{K}$ & $\mathrm{N}$ & $\mathrm{P}$ & $\mathrm{K}$ & $\mathrm{N}$ & $\mathrm{P}$ & $\mathrm{K}$ \\
\hline $\mathrm{C}_{2}$ & 'Rice - pea - summer squash' & 11.2 & 3.0 & 2.0 & 9.7 & 1.8 & 3.8 & 20.9 & 4.8 & 5.8 \\
\hline $\mathrm{C}_{3}$ & 'Okra- radish'- onion' & 8.8 & 1.7 & 2.4 & 9.6 & 1.8 & 3.8 & 18.4 & 3.5 & 6.2 \\
\hline $\mathrm{C}_{4}$ & 'Turmeric - pea - summer squash' & 39.4 & 6.3 & 9.5 & 9.1 & 1.7 & 3.7 & 48.5 & 8.1 & 13.2 \\
\hline $\mathrm{C}_{5}$ & 'Rice - lettuce - potato' & 16.7 & 4.0 & 3.6 & 5.5 & 1.1 & 2.4 & 22.2 & 5.1 & 6.0 \\
\hline $\mathrm{C}_{6}$ & 'Rice - palak - cucumber' & 10.5 & 1.8 & 3.2 & 7.0 & 1.3 & 2.8 & 17.5 & 3.1 & 5.9 \\
\hline $\mathrm{C}_{7}$ & 'Rice - broccoli - radish' & 10.6 & 2.3 & 2.6 & 5.6 & 1.0 & 2.2 & 16.2 & 3.3 & 4.8 \\
\hline $\mathrm{C}_{8}$ & 'Colocasia - pea + coriander' & 13.5 & 2.3 & 4.1 & 7.1 & 1.3 & 2.7 & 20.6 & 3.5 & 6.9 \\
\hline & LSD (P=0.05) & 16.2 & 4.1 & 3.2 & 12.0 & 2.2 & 4.9 & 28.2 & 6.3 & 8.0 \\
\hline
\end{tabular}

Table.4 Yield losses (\%) due to weeds

\begin{tabular}{|l|l|r|r|r|r|r|}
\hline \multicolumn{2}{|c|}{ Cropping system } & \multicolumn{7}{|c|}{ Losses (\%) } \\
\hline & Kharif & Rabi I & Intercrop & Rabi II & Total \\
\hline $\mathrm{C}_{1}$ & 'Rice - wheat' & 34.5 & 26.5 & - & - & 30.6 \\
\hline $\mathrm{C}_{2}$ & 'Rice - pea - summer squash' & 34.6 & 38.6 & - & 28.8 & 35.3 \\
\hline $\mathrm{C}_{3}$ & 'Okra - radish - onion' & 49.9 & 35.4 & - & 50.0 & 43.8 \\
\hline $\mathrm{C}_{4}$ & 'Turmeric - pea - summer squash' & 46.0 & 34.4 & - & 31.3 & 37.8 \\
\hline $\mathrm{C}_{5}$ & 'Rice - lettuce - potato' & 31.6 & 69.1 & - & 9.6 & 33.8 \\
\hline $\mathrm{C}_{6}$ & 'Rice - palak - cucumber' & 30.2 & 70.7 & - & 75.1 & 59.2 \\
\hline $\mathrm{C}_{7}$ & 'Rice - broccoli - radish' & 23.1 & 7.5 & - & 47.9 & 37.9 \\
\hline $\mathrm{C}_{8}$ & 'Colocasia - pea + coriander' & 60.0 & 41.5 & 55.7 & - & 53.8 \\
\hline
\end{tabular}

Fig.1 Proportion of weeds during kharif and rabi
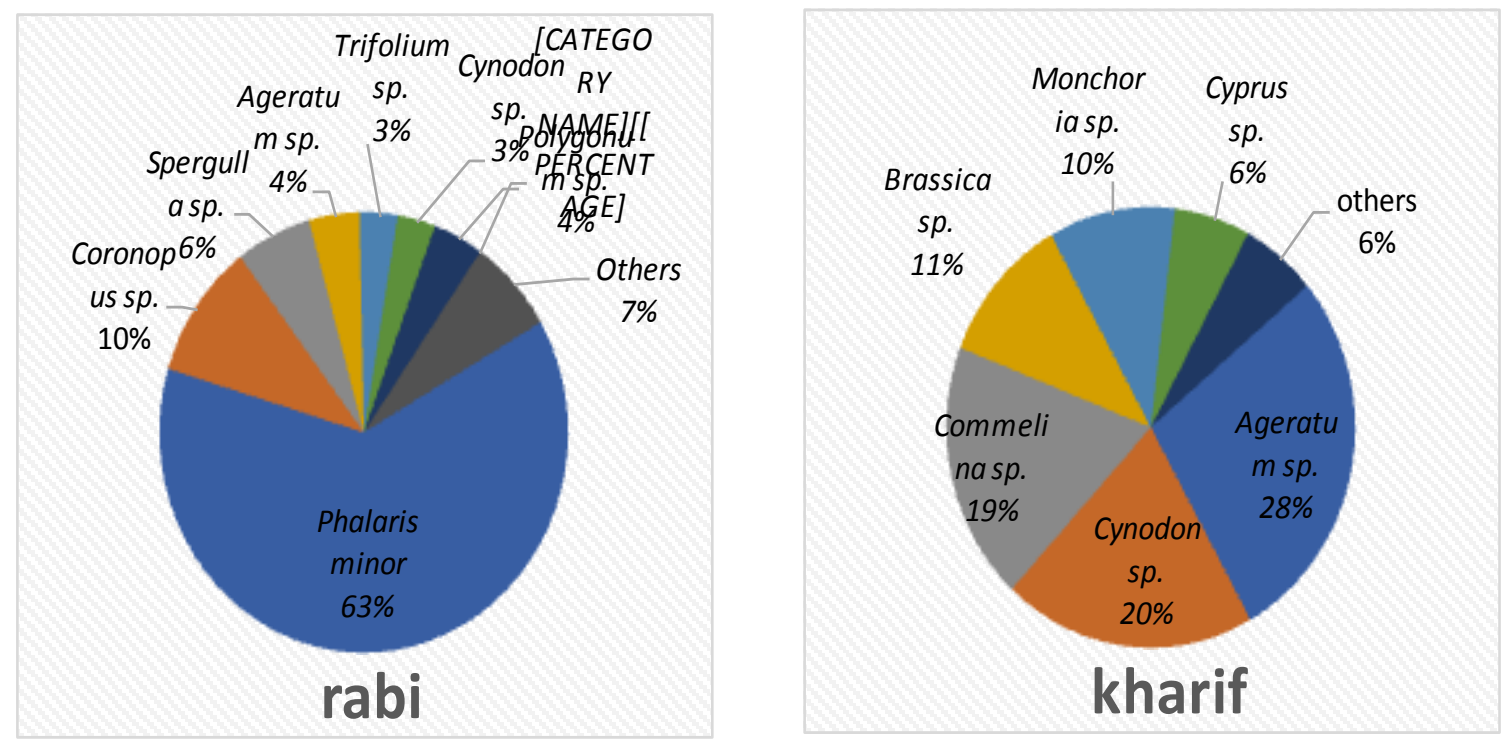
The other cropping systems viz. 'turmeric pea - summer squash', 'rice - pea - summer squash', 'rice - broccoli - radish' and 'rice palak - cucumber' had higher yield than 'rice - wheat'. The data on RGEY shows that its value increased with increase in cropping intensity. Crop intensification with vegetables in systems gave higher RGEY. Higher value of RGEY was obtained from a system of 300 percent cropping intensity, 'colocasia - pea + coriander' while minimum value was recorded from a system having 200 per cent cropping intensity 'rice - wheat'. Colocasia resulted in highest RGEY followed by potato and onion among all crops in various cropping systems.

Rice based vegetable cropping systems resulted in higher rice grain equivalent yield compared to cereal-cereal cropping system. Prasad et al., (2013) reported higher RGEY when 'rice-wheat' cropping system was diversified and vegetable crops were included in system.

Highest energy output of the main product was observed in 'rice - wheat' system.

\section{Nutrient losses by weeds}

The estimates on nutrient losses by weeds are given in Table 3. The nutrient losses due to weeds were huge under the cropping systems. Nitrogen and phosphorous depletion by weeds was higher in rabi compared to kharif. Highest depletion of nutrients was seen in 'okra- radish- onion', followed by 'colocasia - pea + coriander' due to more growth of weeds. High nutrient depletion by weeds from same location was also reported by Suresha et al., (2015) in maize based sequences.

Total yearly NPK depletion by weeds in the other alternative cropping systems was either equal or lower than the conventional 'ricewheat' cropping system.

\section{Yield losses by weeds}

The yield losses estimate due to weeds in the individual crop and combined of the cropping system as a whole are summarized in Table 4. Yield losses in crops due to weeds were computed by comparing per hectare yield of the treatment and weedy situation in each plot. Weeds caused huge yield losses in different cropping systems, ranging from 31 (rice-wheat) to $59 \%$ (rice - palak cucumber). Yield losses in 'rice - wheat' sequence were 34.5 and $26.5 \%$, respectively. Similar results were reported by Yadav et al., (1998) in wheat, when grown in sequence. Yield losses in all the new cropping systems were higher than traditional 'rice-wheat' cropping system. Yield of green leaf crops was highly affected due to weeds followed by vegetable crops. Highest losses were observed in cucumber where weeds resulted in $75 \%$ losses in yield followed by palak with $71 \%$ losses in yield.

The present investigation inferred that weeds are dynamic in nature and they inflict huge yield (31-59\%) and nutrient (16.2-48.5 kg N, $3.1-8.1 \mathrm{~kg} \mathrm{P}$ and $4.8-13.2 \mathrm{~kg} \mathrm{~K}$ per hectare) losses, thereby depriving the crops for want of nutrients. Therefore, careful adoption of crops and cropping systems is needed for successful management of prevalent weed species.

\section{Acknowledgments}

The authors are thankful to CSK Himachal Pradesh Himachal Pradesh Agricultural University, Palampur, India for providing the necessary research facilities.

\section{References}

Anderson R.L. 2011. Synergism: a rotation effect of improved growth efficiency. Advances in Agronomy 112: 205-226 
Black C.A. 1965. Methods of soil analysis. Part II chemical and mineralogical properties. American Society of Agronomy, Madison, Wisconsin, USA

Buriro U.A., Oad F.C., Agha S.K. and Solangi G.S. 2003. Post emergence weed control in wheat. Journal of Applied Sciences 3: 424-427

Colbach N., Biju-Duval L., Gardarin A., Granger S., Guyot S.H.M., Meziere D., Munier-Jolain N.M. and Petit S. 2014. The role of models formulticriteria evaluation and multi-objective design of cropping systems for managing weeds. Weed Research 54:541-555

Gomez K.A. and Gomez A.A. 1984. Statistical Procedures for Agricultural Research. John Wiley and Sons, New York p 680.

Jackson M.L. 1973. Soil Chemical Analysis. Prentice Hall Inc. Englewood Cliffs, New Jersey, USA

Kirkegaard J.A. and Hunt J.R. 2010. Increasing productivity by matching farming system management and genotype in water-limited environments. Journal of Experimental Biology 61: 4129-4143

Prasad D., Yadava M.S. and Singh C.S. 2013. Diversification of rice (Oryza sativa)- based cropping systems for higher productivity, profitability and resourceuse efficiency under irrigated ecosystem of Jharkhand. Indian Journal of Agronomy 58(2): 77-83

Ramanjaneyulu A.V., Sharma R. and Giri G. 2006. Weed shift in rice-based cropping systems - a review. Agricultural Reviews 27(1): 73 - 78

Rao A.N., Wani S.P. and Ladha J.K. 2014. Weed management research in India. An analysis of the past and outlook for future. In: Souvenir (1989-2014). Directorate of Weed Research, Jabalpur, India, Publication No. 18pp. 1-26.

Suresha, Kumar A., Rana S.S., Negi S.C. and Kumar S. 2015. Assessment of yield and nutrient losses due to weeds in maize based cropping systems. Himachal Journal of Agricultural Research 41(1): 42-48

Yadav R.L., Gangwar K.S. and Prasad K. 1998. Dynamics of rice-wheat cropping system in India. Technical Bulletin. Project directorate for Cropping Systems Research, Modipuram, India.

Yaduraju N.T., Sharma A.R. and Rao A.N. 2015. Weeds in Indian agriculture: problems and prospects to become selfsufficient. Indian Farming 65(7): 2-6

\section{How to cite this article:}

Gurpreet Singh, Pawan Pathania, S.C. Negi and Rana, S.S. 2018. Yield and Nutrient Losses Due to Weeds in Prominent Cropping Sequences under Mid Hills of Himachal Pradesh, India. Int.J.Curr.Microbiol.App.Sci. 7(11): 141-147. doi: https://doi.org/10.20546/ijcmas.2018.711.018 